\title{
A New Training Mode of AHK Electro-mechanician --- A Case Study of Nanjing Institute of Industrial Technology
}

\author{
Ling Zhou, Xiaoyong Wang, Jiujun Zhen, Feng Xu， Haichao Song
}

(School of Mechanical Engineering, Nanjing Institute of Industrial Technology, Nanjing, China)

Keywords: AHK, Dual System, Electro-mechanician, Training Mode.

\begin{abstract}
The German certification program of AHK based on "Dual System" has been introduced into China for many years. The traditional model of Chien-Shiung is a kind of training mode based on school mainly; nevertheless when German partner has enough resources by its own, another training mode which depends on German firm mostly could be chosen to cultivate AHK electro-mechanician. This paper introduces the selection of talents, the arrangement of time and content, examinations and payment \& employment in this new mode in details. Finally, some suggestions are put forward to improve the new training mode.
\end{abstract}

\section{Introduction}

German vocational education has a long history, and has made an important contribution to the economic take-off of Germany after the Second World War [1]. The German vocational education model based on "Dual System" has been referred by other countries for many years, and has become the paragon of the development of world vocational Education $[2,3]$. One partner in German "Dual System" refers firm, another one means vocational school [4]. In the German vocational education of "Dual System", apprentices acquire vocational skills and related professional training in company, while learn professional theories and general knowledge in vocational school [4,5]. It utilizes the advantages of both firm and school, combines practical skills with theoretical knowledge, and aims to cultivate professionally high-quality technical workers [6].

AHK Training certificates from German Chamber of Commerce and Industry is a globally recognized vocational education qualification system, which is based on "Dual System" [7]. Through "Dual System" training recognized by AHK institutions, talents who pass relevant examinations can obtain AHK qualification certificate. AHK certificate program relates to many majors, among which mechatronics is one of the focuses of development considering sector allocation of German firms in China [8].

\section{The Traditional Training Mode of AHK Electro-mechanician in China}

Since 2007, Suzhou Chien-Shiung Institute of Technology has become the first which introduces AHK "Dual System" certification system of mechatronics into China [9]. In the past 10 years, led by the Chien-Shiung model, some vocational colleges in China have set up similar "Dual-System" training system. In the Chien-Shiung model, there are many small and medium-sized German firms regionally. These companies recognize the vocational education of "Dual System", and their demand for talents with "Dual System" training is very large. However, due to the limited strength or resource, it is unlikely for these companies to undertake more work in the AHK qualification system except for the post practices. As a result, a training centre is usually set up within the school, whose tasks are organizing AHK examinations and providing training courses of basic technical skills. This mode is based on the "Trinity", i.e. classroom at school, training center at school and post at company; it uses an alternating way to let the student pick up theory and practice training [6].

In recent years, large German industrial companies in China have begun to pay attention to the 
training of AHK electro-mechanician [10]. These companies take a strategy of long-term development in the Chinese market and focus on steady expansion. And their demand for AHK electro-mechanician with "Dual System" vocational education shows a growing trend. Considering their abundant resources, companies are usually willing to set up an internal training center instead of one at school; and this training center at company undertakes AHK examinations and training of apprentices etc. On the basis of complementary advantages in cooperation, school and German company jointly establish a "Dual System" training mode of AHK electro-mechanician, where the company plays a leading role.

\section{A New Training Mode of AHK Electro-mechanician}

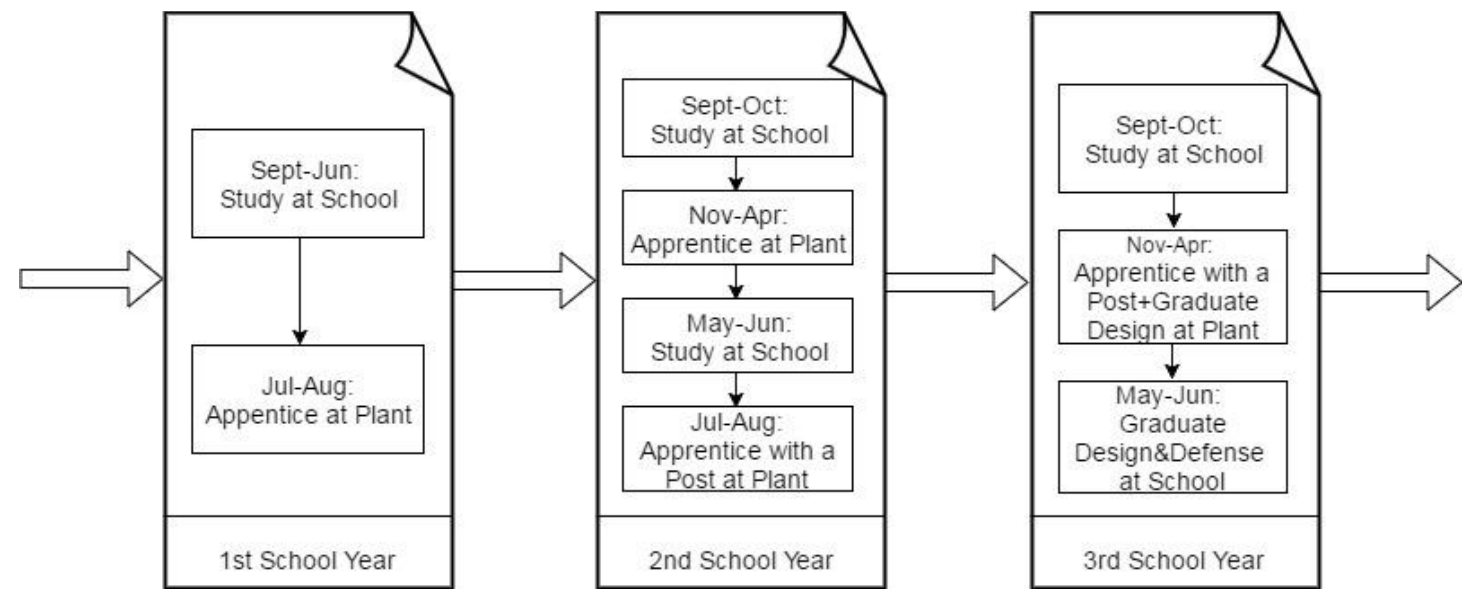

Figure 1: Arrangement of AHK Electro-mechanician in the New Mode

\subsection{Selection}

AHK electro-mechanician program is suited for three-year students who major in mechatronics and pass national College Entrance Examination in China. By the end of the first school year, company organizes examinations at school. Examination includes interview, written test and hands-on one. What it involves is the basic thinking and hands-on ability of examinee, but not professional knowledge and skills.

\subsection{Arrangement of Time and Content}

Students start apprenticeship at company on the summer vacation of $1^{\text {st }}$ school year. During the next two school years, usually students work at school for roughly 4 months and at plant for around 8 months each year. Actually 4 months include 2 periods: May-June and September-October, while 8 months is separated into July-August and November-April of the near year. The program alternates between school period and company period (Figure 1), and there are totally four company periods.

During the first two company periods, students work mainly in the in-house training center at plant. Guided by different master, they can acquire a variety of professional skills, such as operating milling, drilling and grinding machine and so on. During the last two company periods, apprentices practice at different post in different department. During every school year period, students pick up intensive courses and training. Between November of the third school year and April of next year, students do post practice at plant while working out graduate design with the teacher of school at the same time.

\subsection{Examination}

During the two-year apprenticeship, students must take the two Examinations of AHK. The first examination is organized by company, and it takes place in company during the second half of the second school year; school teachers and judges of AHK organization will present for the supervision. The first examination includes written test, hands-on and oral part respectively. 
Hands-on test mainly involves work piece processing, electrical wiring; nevertheless programming of control system does not be required. Generally the written test focuses on the knowledge and skills related to hands-on test. The second examination of AHK is hold in the mid April of the third school year.

\subsection{Salary and Employment}

During the apprenticeship of around two-year period, student will contract with company while still keep a status as student at school. Company provides a living allowance and some basic benefits. Students will usually work at the same company after they obtain graduation certificate from school. And company will determine the salary of these new employees according to their AHK examination.

\section{Suggestions and Conclusion}

The new training mode of AHK electro-mechanician where company plays a key role, has been developed during these years; nevertheless its arrangement and organization still need to improve. For example, there is only totally 4 months at school in the second school year; students need to complete all the courses which other students not joining the program take in 8 months. For students lacking of competence, intensive learning probably adversely affect their learning effectiveness. One measure is to optimize all the content of courses at school according to the requirements of AHK certification program. For example courses or training at school will not or at least less include the content which will be imparted at company. Moreover curriculum focuses more on practical knowledge than knowledge of theory.

During the apprenticeship at plant, master mainly imparts practical skills of relevant post to apprentices; whereas apprentices need to learn basic capacities by themselves in the spare time. To boost learning among students, it is suggested that school teachers with solid technical background provide guidance for students even in the period of apprenticeship at company.

\section{Acknowledgement}

This research was financially supported by College Brand Specialty Construction Project of Jiangsu Provice (PPZY2015A087), Higher Education Reform Research Project of Jiangsu Province (2017JSJG289), Higher Vocational Education Research Core Project of Nanjing Institute of Industrial Technology (GJ17-04Z), and The 14th "Six-talent Peak" High Level Talents Project of Jiangsu Province (GDZB-031)

\section{References}

[1] Y. B. Hou, The exploration and practice of German dual-system vocational education in China, Science, Technology and Information, vol.36, pp. 356-359, 2010. (In Chinese)

[2] J. Yin, A study on the promotion of specialty construction by German AHK accreditation system, Journal of Taiyuan City Vocational and Technical College, vol.04, pp. 121-124, 2015. (In Chinese)

[3] C. P. Xiao, On the Enlightenment of the German "dual system" vocational education on the trial of modern apprenticeship system in our vocational colleges, [Higher Education Forum] World, vol.12, pp.177-178, 2015. (In Chinese)

[4] H. L. Zhou, W. Z. Zhang, A study of German modern apprenticeship system in the view of human capital theory, Exploration of Higher education, vol. 4, pp. 48-52, 2014. (In Chinese)

[5] W. Mitter, Fundamental questions of the relationship between general education and vocational education, International Review of Education, vol.24 (2), pp.117-129, 1978.

[6] G. Kutscha, On the relationship between general education and vocational training in the 
context of education-theoretical reform concepts --- review and perspectives, Journal of Vocational and Economic Education, vol. 99, pp. 328-349, 2003.(In German)

[7] R. Nickolaus, The tasks of the vocational school in the "dual system, http://www.uni-stuttgart.de, 1998 (In German)

[8] http://china.ahk.de/services/recruitment-training-vocational-training/voctrain/ , Vocational Training Mainland China

[9] http://www.wjxvtc.cn/s/22/t/5/10/b6/info4278.htm, AHK-shanghai Chien-Shiung Institute of Technology, Training Center of Technical Worker

[10]L. Zhou, Analysis of Demand for AHK Apprentices at German Firms in Nanjing, Research Report, 2017. 